\title{
An overview of ultracapacitors applicability in high power applications
}

\author{
V. López ${ }^{1}$, J.L. Martín ${ }^{1}$, I. Martínez de Alegría ${ }^{1}$, O. Oñederra ${ }^{1}$ and H. Ibaiondo ${ }^{2}$ \\ ${ }^{1}$ Department of Electronics Technology \\ Faculty of Engineering (ETSI Bilbao), University of the Basque Country (UPV/EHU) \\ Alda. Urkijo s/n, 48013 Bilbao (Spain) \\ e-mail: victormanuel.lopez@ehu.es, joseluis.martin@ehu.es \\ ${ }^{2}$ Ingeteam Power Technology S.A. \\ Bizkaia Technology Park, Building 702, 48160 Derio (Spain) \\ e-mail: harkaitz.ibaiondo@ingeteam.com
}

\begin{abstract}
Ultracapacitors are entering into applications dominated by batteries. The complementary features of ultracapacitors and batteries may allow in certain applications to combine them enhancing the performance of the overall energy storage system. In other applications, the advantages of ultracapacitors may allow to completely displaced batteries avoiding some of its drawbacks. Determined key issues and weaknesses of ultracapacitors are being intensively researched, leading to a greater applicability of ultracapacitors.
\end{abstract}

\section{Key words}

Ultracapacitor, supercapacitor, battery, energy storage, high power applications

\section{Introduction}

Ultracapacitors (also known as supercapacitors) have taken off in recent years in high power applications [1],[2]. The evolution of the technology of ultracapacitors has placed them in good position in the field of energy storage technologies [3].

In applications in which batteries used to dominate the market, developments combining ultracapacitors or even based only on ultracapacitors are being implemented due to their advantages [4].

This article aims to give an overview of the applicability of ultracapacitors in high power applications and the research which may improve it. In section 2, intern structure of ultracapacitors is described. In section 3 , a comparison of features of ultracapacitors and batteries is presented. In section 4, high power applications representing a clear relevant nest for ultracapacitors are presented. In section 5, the research needed to increase ultracapacitors application opportunities is presented. Finally, conclusions are presented in section 6 .

\section{EDLC and AEDLC}

Ultracapacitors are divided into two different types: symmetric (EDLC) and asymmetric (AEDLC). The first and most common type consist of two porous activated carbon electrodes on current collectors and separated by an insulating dielectric separator. The electrodes are immersed in an electrolyte composed of ions (positive and negative) dissolved in a solvent (Fig. 1). A difference of potential between the current collectors attracts the opposite-charged ions to the carbon electrodes, achieving energy storage by an electric field, in contrast to the batteries in which a chemical reaction is generated. A high capacitance results from the very large area of the electrodes and its extreme closeness.

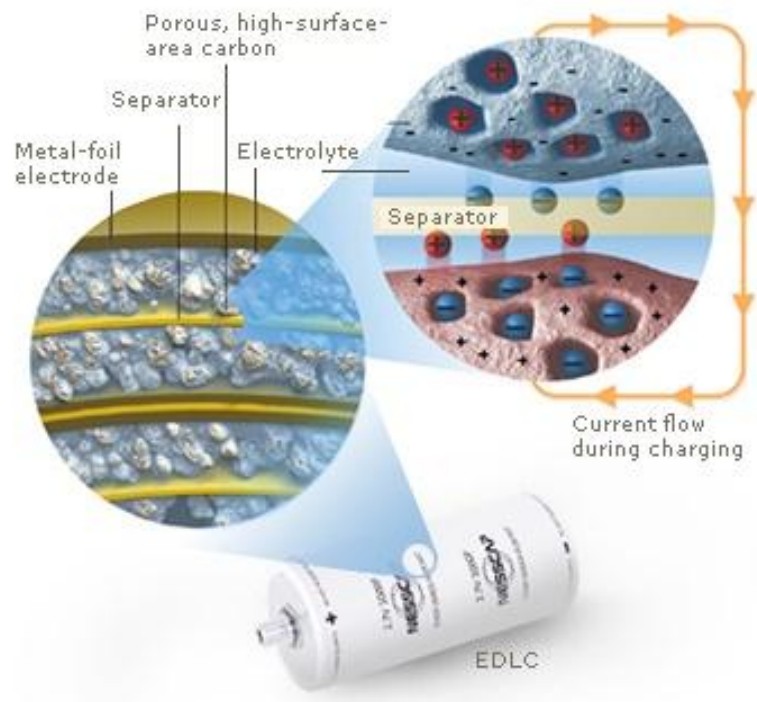

Fig. 1. Internal structure of an ultracapacitor [5]

In an asymmetric ultracapacitors one of the electrodes has been replaced by, for example, a battery type 
electrode. This change provides a mixture of features of ultracapacitors and batteries, increasing energy density compared to a symmetric ultracapacitor and narrowing the voltage variation. However, it also increases charge/discharge times and shortens cycle life. Asymmetric ultracapacitors would be suitable for applications without heavy-duty cycling, such as UPS or power backup.

\section{Ultracapacitors vs. batteries}

Points of comparison between batteries and ultracapacitors are shown in table I.

Table I. - Features of ultracapacitors and batteries comparison

\begin{tabular}{ll}
\hline \multicolumn{1}{c}{ Ultracapacitor } & \multicolumn{1}{c}{ Battery } \\
\hline $\begin{array}{l}\text { Low energy density } \\
\text { Very high power }\end{array}$ & High energy density \\
Very long cycle life & Medium power \\
\hline $\begin{array}{l}\text { Voltage depends on the state of } \\
\text { charge }\end{array}$ & $\begin{array}{l}\text { Short cycle life } \\
\text { Voltage relatively constant }\end{array}$ \\
$\begin{array}{l}\text { Sized to fit power profile } \\
\text { High efficiency }\end{array}$ & Sized to fit energy profile \\
$\begin{array}{l}\text { Performance decreases } \\
\text { smoothly }\end{array}$ & $\begin{array}{l}\text { Medium efficiency } \\
\text { Performance decreases } \\
\text { Quick charges/discharges }\end{array}$ \\
$\begin{array}{l}\text { Slow charges/medium } \\
\text { discharges }\end{array}$ \\
temperatures & $\begin{array}{l}\text { Bad performance at very low } \\
\text { temperatures }\end{array}$ \\
\hline
\end{tabular}

The capacitance of an ultracapacitor changes with temperature variation, during charge/discharge and during the cycle life [6]. This affects directly to its energy density and consequently to its voltage, hindering partly its control. The energy density of a battery also changes with some parameters, but its chemical behavior keeps relatively constant its voltage.

Considering energy and power density, batteries and ultracapacitors are complementary (Fig. 2).

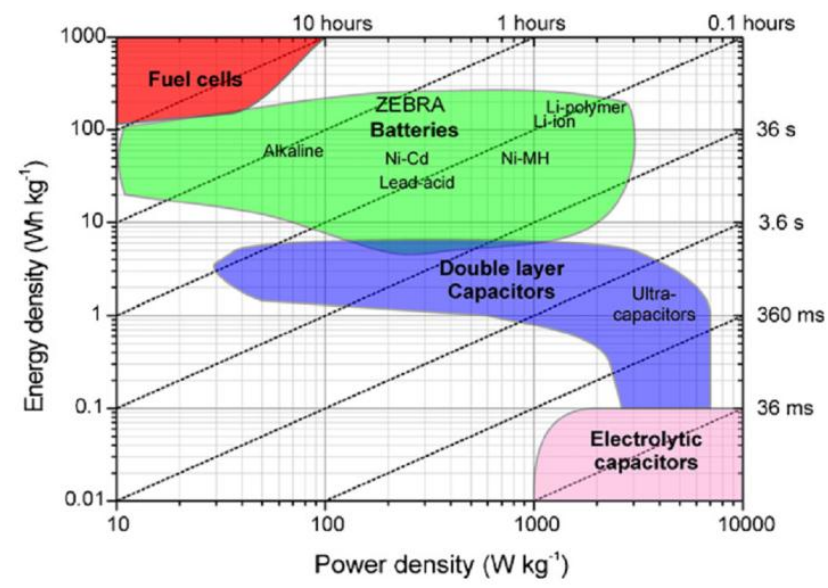

Fig. 2. Ragone diagram [7]

\section{High power applications}

However, in many applications, ultracapacitors are in direct competition with batteries. Those in which the energy density needed is relatively low, ultracapacitors (EDLC and AEDLC) compete with lead-acid and nickelmetal hydride batteries, due to the medium energy density of these technologies. Those in which the energy density represents the main goal lithium-ion batteries are the best solution. But in those applications in which a high power (or other ultracapacitors remarkable features such as long cycle life) is critical, ultracapacitors has no competitors [8].

Applications requiring relatively large capacitances and representing a clear relevant nest for ultracapacitors are listed below.

1) Hybrid \& pure electric on-road vehicles. Batteries could be completely replaced in electric buses (where a quick charge could be made in every stop), or can be combine with ultracapacitors avoiding oversizing the batteries [9],[10]. In addition, ultracapacitors facilitate energy harvesting during braking [11].

2) Railways. As in electric buses, in light trains ultracapacitors could be combined with batteries [12],[13] or replace them and could be charged in the stations. A 27 second charge may allow reaching a $2 \mathrm{~km}$ distance [14].

3) Wind turbines. Replace big batteries banks by ultracapacitors acting in drops of electrical grid [15]. Ultracapacitors react quicker and more reliably [16].

4) Grid storage and grid power factor correction and frequency control. As in wind turbines, the quick reaction and instantaneous power of an ultracapacitors bank could give the necessary energy to control diversions of the main parameters of electrical grid [17],[18].

5) UPS. Short start up times is required to compensate the main source fall. Ultracapacitors are suitable since can bridge power developing a high current very quickly [19],[20].

6) Heavy pulse power. Ultracapacitors can work in parallel with batteries smoothing the peak currents and extending the battery life [21],[22].

In order for ultracapacitors to provide the benefits shown above, a restriction must be addressed. In high power applications, DC link of power electronics converters is the common point for the connection of ultracapacitors [23]. DC links usually operate at high voltages. Considering that, voltage ratio of ultracapacitors cells represents a clear restriction due to two basic reasons. On the one hand, their rated voltage is extremely low, ranging from $1 \mathrm{~V}$ to $2,8 \mathrm{~V}$ depending on the electrolyte technology [24]. And on the other hand, their voltage depends on the state of charge, usually ranging from $50 \%$ to $100 \%$ of the rated voltage [23]. Thereby, a series connection of ultracapacitors is necessary to reach workable voltages. However, this connection brings the problem of the non-uniformity of some parameters of ultracapacitors, mainly the capacitance. A different state of charge, derived from a different capacitance, will end in a drop in performance and lifespan. 
Table II. - Ultracapacitor modules parameters

\begin{tabular}{|c|c|c|c|c|c|c|c|c|c|c|}
\hline $\begin{array}{c}\text { Capacitance } \\
\text { (F) }\end{array}$ & $\begin{array}{c}\text { Rated } \\
\text { voltage } \\
\text { (V) }\end{array}$ & $\begin{array}{c}\text { Max. } \\
\text { current } \\
\text { (A) }\end{array}$ & $\begin{array}{c}\text { Leakage } \\
\text { current } \\
(\mathbf{m A})\end{array}$ & $\begin{array}{c}\text { ESR } \\
\text { DC } \\
(\mathrm{m} \Omega)\end{array}$ & $\begin{array}{c}\text { Max. } \\
\text { power } \\
(\text { W/kg) }\end{array}$ & $\begin{array}{c}\text { Energy } \\
\text { density } \\
(\mathrm{Wh} / \mathbf{k g})\end{array}$ & $\begin{array}{l}\text { Mass } \\
(\mathrm{kg})\end{array}$ & $\begin{array}{c}\text { Temp. } \\
\left({ }^{\circ} \mathrm{C}\right)\end{array}$ & $\begin{array}{c}\text { Voltage } \\
\text { balance } \\
\text { type }\end{array}$ & Manufacturer \\
\hline 500 & 16 & 2000 & $\begin{array}{l}5,2 \\
170\end{array}$ & 2,1 & 5500 & 3,2 & 5,51 & -40 to +65 & $\begin{array}{l}\text { Active } \\
\text { Passive }\end{array}$ & \multirow{5}{*}{ Maxwell [25] } \\
\hline 165 & 48 & 1900 & 5,2 & 6,3 & 6800 & 3,9 & 13,5 & -40 to +65 & Active & \\
\hline 130 & 56 & 1800 & 120 & 8,1 & 5400 & 3,1 & 18 & -40 to +65 & Passive & \\
\hline 94 & 75 & 1600 & 50 & 13 & 4300 & 2,9 & 25 & -40 to +65 & Passive & \\
\hline 63 & 125 & 1800 & 10 & 18 & 3600 & 2,3 & 60,5 & -40 to +65 & Active & \\
\hline 500 & 16 & 2020 & 5,2 & 1,9 & 5614 & 3,03 & 6 & -40 to +65 & Active & \multirow{5}{*}{ Nesscap [5] } \\
\hline 166 & 48 & 2030 & 5,2 & 5,6 & 6857 & 3,63 & 15 & -40 to +65 & Active & \\
\hline 125 & 64 & 2030 & 5,2 & 7,5 & 7186 & 3,83 & 19 & -40 to +65 & Active & \\
\hline 93 & 86 & 2030 & 5,2 & 7,5 & 9482 & 3,7 & 26 & -40 to +65 & Active & \\
\hline 62 & 125 & 1850 & 5,2 & 15 & 4569 & 2,36 & 57 & -40 to +65 & Active & \\
\hline
\end{tabular}

Table III. - Battery modules parameters

\begin{tabular}{cccccccccc}
\hline $\begin{array}{c}\text { Capacity } \\
(\mathbf{A h})\end{array}$ & $\begin{array}{c}\text { Voltage } \\
(\mathbf{V})\end{array}$ & $\begin{array}{c}\text { Max. } \\
\text { discharge } \\
\text { current }(\mathbf{A})\end{array}$ & $\begin{array}{c}\text { Internal } \\
\text { resist. } \\
(\mathbf{m} \boldsymbol{\Omega})\end{array}$ & $\begin{array}{c}\text { Energy } \\
\text { density } \\
(\mathbf{W h} / \mathbf{k g})\end{array}$ & $\begin{array}{c}\text { Mass } \\
(\mathbf{k g})\end{array}$ & $\begin{array}{c}\text { Temp. } \\
\left({ }^{\circ} \mathbf{C}\right)\end{array}$ & Technology & $\begin{array}{c}\text { Lifetime at } \\
\mathbf{1 0 0 \%} \text { DOD } \\
(\mathbf{c y c l e s})\end{array}$ & $\begin{array}{c}\text { Manufacturer } \\
\end{array}$ \\
\hline 45 & 48 & 50 & - & 115 & 19 & -20 to +60 & Li-Ion & 8000 & Saft $[26]$ \\
45 & 38,4 & 90 & 25 & 91 & 19,6 & 0 to +45 & LiFeMgPO4 & 2800 & Valence $[27]$ \\
\hline
\end{tabular}

Some voltage balancing strategies have been proposed in the literature to overcome this problem [28]-[29]. More common solutions are voltage balancing circuits, going from a resistance in parallel with each cell (passive balancing) to those including semiconductors (active balancing) [30]-[31], that is, going from circuits with high losses to those offering the possibility of individual control of each cell of the ultracapacitors stack. Leakage current values shown in table II represent a good evidence of the losses of passive balancing.

Many are the manufacturers offering a wide range of ultracapacitors for relatively low power applications, such as Panasonic and Nichicon. By contrast, few are the ones able to offer a well-tested range of modules of ultracapacitors. Nesscap and Maxwell are two of those manufacturers, and the parameters of a sample of their modules are shown in table II. The parameters of two battery modules are presented for comparison in table III.

\section{Improves being research}

In order to increase ultracapacitors application opportunities some features must be improved. Some of them are described below.

1) Increase of energy density (per weight unit) [19] and decrease of prices [20]. This is the most important research being carried out. Batteries are far ahead with energy densities 10 times higher, a partial improvement may allow ultracapacitors to replace more batteries in applications in which ultracapacitors are now used only for protecting batteries from power peaks. Less batteries means avoiding their disadvantages, e.g. system reliability and performance would be increased [32].

2) Longer life guarantees. Ultracapacitors have a lifetime of more than a million of cycles, namely, far greater than that of batteries. However during its lifetime, changes in their parameters occur. That is the reason why, although ultracapacitors might reach 20 years of lifetime [33], commercial guarantees rarely reach ten years. Methods to increase ultracapacitors lifetime are being develop [34], such that guarantees may extend leaning on them.

3) Increase operation frequency. Internal charge redistribution takes place inside an ultracapacitor. That phenomenon, along the inductive effect appearing at high frequencies, represents a constraint on ultracapacitors performance in pulse power applications. As that constraint is intrinsic to its manufacturing, research has focused on modelling [23].

4) Non-toxic, inflammable, environmentally friendly materials. Some electrolytes used in ultracapacitors are toxic and flammable, such as acetonitrile. Moreover, in high volume on-board applications, non-toxic non-flammable materials are desired for improving safety. Although there are non-toxic alternatives [35], there is still a wide field to research so that they catch up the whole performance of the toxic ones.

5) Reduce leakage. Although it is already low, it would improve applicability in medium time energy storage. Active balancing substantially avoids increasing it, but it can't compete in long time energy storage with the $5 \%$ of discharge per month of a battery. 
6) Reduce capacitance drop. Capacitance in ultracapacitors is reduced during discharge and during cycle life [6]. Improving this fact would ease the application of ultracapacitors where it's difficult to replace them, such as in ultracapacitors banks near wind turbines.

Increasing energy density (desirable to compete in volume/weight), reducing prices (desirable to compete economically) and increasing life cycle (desirable to compete in durability and reduce of maintenance) are the three key issues more interesting to be reached.

\section{Conclusion}

Although ultracapacitors aren't extended as a standard in many applications (usually because of their price), their use should be justified because of the energy savings achieve and also due to the longer cycle and the mistreatment resistance that characterize the ultracapacitors in comparison with batteries.

Taking into account the research being carried out to overcome ultracapacitors weaknesses, the nest of application in which they can be applied and can replace other technologies such as batteries will increase considerably.

\section{Acknowledgement}

This work has been carried out inside de Research and Education Unit UFI11/16 of the UPV/EHU and supported by the Department of Education, Universities and Research of the Basque Government within the fund for research groups of the Basque university system IT394-10, and the fund of a grant for training of research personnel of the UPV/EHU.

\section{References}

[1] T. Sels et al., "Overview of new energy storage systems for an improved power quality and load managing on distribution level", in Proc. of International Conference and Exhibition on Electricity Distribution (CIRED), 2001, pp. 1 - 5.

[2] R. B. Schainker, "Executive overview: energy storage options for a sustainable energy future", in Proc. of IEEE Power Engineering Society General Meeting, 2004, pp. 2309 - 2314.

[3] M. A. Guerrero, "Overview of medium scale energy storage systems", in Proc. of Compatibility and Power Electronics (CPE), 2009, pp. $93-100$.

[4] M. S. Whittingham, "History, Evolution, and Future Status of Energy Storage", in Proceedings of the IEEE, 2012, Vol. 100, pp. $1518-1534$

[5] Nesscap, "Power to move", Product Guide - Catalog, 2012.

[6] N. Rizoug, P. Bartholomeus and P. Le Moigne, "Study of the Ageing Process of a Supercapacitor Module Using Direct Method of Characterization", in IEEE Transactions on Energy Conversion, 2012, Vol. 27, pp. $220-228$.

[7] Q. Cai et al., "A sizing-design methodology for hybrid fuel cell power systems and its application to an unmanned underwater vehicle", in Journal of Power Sources, 2010, Vol. 195 , pp. $6559-6569$.

[8] A. Kusko and J. DeDad, "Stored energy - Short-term and long-term energy storage methods", in IEEE Industry Applications Magazine, 2007, Vol. 13, pp. 66 - 72.
[9] Y. Tang and A. Khaligh, "Bidirectional hybrid Battery/ Ultracapacitor Energy Storage Systems for next generation MVDC shipboard power systems", in Proc. of IEEE Vehicle Power and Propulsion Conference (VPPC), 2011, pp. 1 - 6.

[10] A. L. Allegre, A. Bouscayrol and R. Trigui, "Influence of control strategies on battery/supercapacitor hybrid Energy Storage Systems for traction applications", in Proc. of IEEE Vehicle Power and Propulsion Conference (VPPC), 2009, pp. $213-220$.

[11] I. Roasto, "Control of Ultracapacitors Energy Exchange", in Proc. of International Power Electronics and Motion Control Conference (EPE-PEMC), 2006, pp. 1401 - 1406.

[12] J. Baert, "Sizing of a hybrid locomotive", in Proc. of IEEE Vehicle Power and Propulsion Conference (VPPC), 2011, pp. 1 -6 .

[13] H. Hoimoja, D. Vinnikov and T. Jalakas, "Analysis and design of ultracapacitor-boosted back-up power supply for tramcars", in Proc. of IEEE EUROCON, 2009. pp. 583 - 589.

[14] M. Steiner, M. Klohr and S. Pagiela, "Energy storage system with ultracaps on board of railway vehicles", in Proc. of European Conference on Power Electronics and Applications (EPE), 2007, pp. 1 - 10.

[15] C. Abbey and G. Joos, "Supercapacitor Energy Storage for Wind Energy Applications", in IEEE Transactions on Industry Applications, 2007, Vol. 43, pp. 769 - 776.

[16] Wook-Won Kim and Jin-O Kim, "Reliability cost of battery with wind farm", in Proc. of IEEE TENCON, 2011, pp. $981-985$.

[17] A. Virtanen and H. Tuusa, "Power compensator for high power fluctuating loads with a supercapacitor bank energy storage", in Proc. of IEEE International Power and Energy Conference (PECon), 2008, pp. 977 - 982.

[18] Z. Xi, B. Parkhideh and S. Bhattacharya, "Improving distribution system performance with integrated STATCOM and supercapacitor energy storage system", in Proc. of IEEE Power Electronics Specialists Conference (PESC), 2008, pp. $1390-1395$.

[19] T. Olivo, "Analysis of ultra capacitors as UPS energy storage devices", in Proc. of IEEE SoutheastCon, 2010, pp. 398 $-401$.

[20] P. J. Binduhewa, "Uninterruptible power supply for shorttime power back-up using ultracapacitors", in Proc. of IEEE International Conference on Industrial and Information Systems (ICIIS), 2011, pp. 551 - 556.

[21] J. P. Zheng et al., "Hybrid power sources for pulsed current applications", in IEEE Transactions on Aerospace and Electronic Systems, 2001, Vol. 37, pp. 288 - 292.

[22] A. Kuperman et al., "Design of a Semiactive BatteryUltracapacitor Hybrid Energy Source", in IEEE Transactions on Power Electronics, 2013, Vol. 28, pp. 806 - 815.

[23] I. Aharon and A. Kuperman, "Topological Overview of Powertrains for Battery-Powered Vehicles With Range Extenders", in IEEE Transactions on Power Electronics, 2011, Vol. 26, pp. 868 - 876.

[24] P.J. Grbovic et al., "The Ultracapacitor-Based Controlled Electric Drives With Braking and Ride-Through Capability: Overview and Analysis", in IEEE Transactions on Industrial Electronics, 2011, Vol. 58, pp. 925 - 936.

[25] Maxwell Technologies, "Product comparison matrix", Product Information, 2012.

[26] Saft, "Synerion 48E", Datasheet, 2012.

[27] Valence, "U27-36XP", Datasheet, 2012.

[28] D. Linzen et al., "Analysis and evaluation of chargebalancing circuits on performance, reliability, and lifetime of supercapacitor systems", in IEEE Transactions on Industry Applications, 2005, Vol. 41, pp. 1135 - 1141.

[29] J. Jang, J. Nam and J. Yoo, "Cell Balancing Circuit Implementation with DC/DC Converters Using Super Capacitor Equivalent Circuit Parameters", in Proc. of IEEE Vehicle Power and Propulsion Conference (VPPC), 2007, pp. 646 - 653. 
[30] M. Uno and K. Tanaka, "Single-switch cell voltage equalizer using voltage multipliers for series-connected supercapacitors", in Proc. of IEEE Applied Power Electronics Conference and Exposition (APEC), 2012, pp. 1266 - 1272.

[31] K. Matsui, T. Nakashima and M. Hasegawa, "Analyses of voltage equalizer for supercapacitors using $\mathrm{CW}$ circuit having buck-boost chopper", in Proc. of WSEAS/IASME International Conference on Electric Power Systems, High Voltages, Electric Machines and WSEAS International Conference on Remote Sensing, 2010, pp. 89 - 94.

[32] B. Maher, "Ultracapacitors: The Battery-less, High Reliability Back-up Solution", in Proc. of International Telecommunications Conference (INTELEC), 2005, pp. 321 326.
[33] A. Helwig and T. Ahfock, "Ultra-capacitor assisted battery storage for remote area power supplies: A case study", in Proc. of Australasian Universities Power Engineering Conference (AUPEC), 2009, pp. 1 - 9.

[34] S. Basu and T. M. Undeland, "Voltage and current ripple considerations for improving lifetime of Ultra-Capacitors used for energy buffer applications at converter inputs", in Proc. of IEEE Applied Power Electronics Conference and Exposition (APEC), 2010, pp. 244 - 247.

[35] G. Mills, S. N. Venkateswaran, "High voltage non-toxic electrolytes for ultracapacitors", Patent US20080137265A1, 2008. 